\title{
Development and Characterization of Acellular Porcine Pulmonary Valve Scaffolds for Tissue Engineering
}

\author{
Ji Luo, PhD, ${ }^{1}$ Sotirios A. Korossis, PhD, ${ }^{2}$ Stacy-Paul Wilshaw, PhD, ${ }^{1}$ Louise M Jennings, PhD, \\ John Fisher, $\mathrm{PhD}$, and Eileen Ingham, $\mathrm{PhD}^{1}$
}

Currently available replacement heart valves all have limitations. This study aimed to produce and characterize an acellular, biocompatible porcine pulmonary root conduit for reconstruction of the right ventricular outflow tract e.g., during Ross procedure. A process for the decellularization of porcine pulmonary roots was developed incorporating trypsin treatment of the adventitial surface of the scraped pulmonary artery and sequential treatment with hypotonic Tris buffer (HTB; $10 \mathrm{mM}$ Tris $\mathrm{pH} 8.0,0.1 \%$ (w/v) EDTA, and $10 \mathrm{KIU}$ aprotinin), $0.1 \%(\mathrm{w} / \mathrm{v})$ sodium dodecyl sulfate in HTB, two cycles of DNase and RNase, and sterilization with $0.1 \%(\mathrm{v} / \mathrm{v})$ peracetic acid. Histology confirmed an absence of cells and retention of the gross histoarchitecture. Immunohistochemistry further confirmed cell removal and partial retention of the extracellular matrix, but a loss of collagen type IV. DNA levels were reduced by more than $96 \%$ throughout all regions of the acellular tissue and no functional genes were detected using polymerase chain reaction. Total collagen levels were retained but there was a significant loss of glycosaminoglycans following decellularization. The biomechanical, hydrodynamic, and leaflet kinematics properties were minimally affected by the process. Both immunohistochemical labeling and antibody absorption assay confirmed a lack of $\alpha$-gal epitopes in the acellular porcine pulmonary roots and in vitro biocompatibility studies indicated that acellular leaflets and pulmonary arteries were not cytotoxic. Overall the acellular porcine pulmonary roots have excellent potential for development of a tissue substitute for right ventricular outflow tract reconstruction e.g., during the Ross procedure.

\section{Introduction}

$\mathbf{H}$ EART VALVE DYSFUNCTION has a global prevalence, and the aortic valve is the one that is most often replaced. Replacement valves may be mechanical, bioprosthetic, cryopreserved homografts, or autografts. All valve replacements have their own advantages and disadvantages, and none of them is ideal. Acellular natural tissue cardiac valves offer an opportunity to create "ideal replacement valves," with the potential to overcome the limitations of currently available replacements, including risk of thromboembolism, requirement for life-time anticoagulation therapy, poor durability and abnormal hydrodyamics. For the pediatric population, acellular heart valves may offer the optimal solution since they should have the potential to grow, repair, and remodel. ${ }^{1-3}$

The Ross procedure is used to treat severe aortic valve disease in young patients. The patient's own pulmonary valve is used to replace the diseased aortic valve. ${ }^{4}$ Pulmonary homografts are considered the gold standard for right ventricular outflow tract (RVOT) reconstruction e.g., during the Ross procedure. ${ }^{5,6}$ The general outcome is good with a high survival and low reoperation rate. However, there are risk factors ${ }^{7,8}$ and the pulmonary homografts will eventually suffer from stenosis and deterioration over time. ${ }^{9}$ The use of acellular natural valves in the pulmonary position is therefore currently of major interest.

Different methods have been utilized to generate acellular pulmonary valve conduits including the use of detergents such as $0.1 \%(\mathrm{w} / \mathrm{v})$ sodium dodecyl sulfate $(\mathrm{SDS})^{10,11}$ and Triton X-100, ${ }^{12} 0.1 \%$ (w/v) deoxycholic acid, ${ }^{6}$ and enzymes such as trypsin ${ }^{13}$ and nuclease. ${ }^{14}$ Currently, acellular pulmonary homograft valves are used clinically. Da Costa et al. ${ }^{10}$ demonstrated that pulmonary homografts decellularized using $0.1 \%(\mathrm{w} / \mathrm{v})$ SDS had low gradients over a 24 months followup with an absence of any immunological reaction without elevation of antibodies to donor MHC Class I and II. The SynerGraft ${ }^{\mathrm{TM}}$ pulmonary homograft (Cryolife, Inc.), which was treated by a proprietary process designed to substantially reduce leaflet and conduit cellularity, is available commercially, and early results have showed that it was as competent as cryopreserved homografts. ${ }^{15}$ However, there are, as yet, no

\footnotetext{
${ }^{1}$ Institute of Medical and Biological Engineering, The University of Leeds, Leeds, United Kingdom.

${ }^{2}$ Lower Saxony Centre for Biomedical Engineering Implant Research and Development, Hanover Medical School, Hanover, Germany.
} 
apparent clinical advantages to the use of the SynerGraft ${ }^{\mathrm{TM}}$ pulmonary homograft over cryopreserved homografts. The real test will be the comparative performance at 8-12 years, when the cryopreserved homografts begin to suffer calcification and degeneration. It is important to recognize, however, that if acellular pulmonary homografts show advantages over cryopreserved homografts in the longer term, there will still be limitations in terms of the availability of human donor tissue, especially for pediatric applications.

CryoLife applied the SynerGraft ${ }^{\mathrm{TM}}$ process to porcine pulmonary valves. These valves however, failed catastrophically in children due to severe inflammatory reactions most likely caused by incomplete decellularization with residual xenogeneic cells. ${ }^{16}$ Other acellular pulmonary xenografts that have been used clinically include the Matrix $\mathrm{P}^{\mathrm{TM}}$ and Matrix $\mathrm{P}^{\mathrm{TM}}$ Plus porcine pulmonary valve (AutoTissue). The Matrix $\mathrm{P}$ porcine pulmonary valve (AutoTissue) comprised an acellular porcine pulmonary valve supported by a glutaraldehydefixed equine pericardial patch. ${ }^{17}$ Konertz et al. ${ }^{18}$ reported on the intermediate-term clinical performance of Matrix $\mathrm{P}^{\mathrm{TM}}$ $(n=9)$ and Matrix PTM Plus $(n=52)$ implantation. The grafts were favorable compared to other currently available implants. A number of other studies later reported inflammatory responses to the Matrix $\mathrm{P}^{\mathrm{TM}}$ porcine pulmonary grafts associated with peripheral conduit narrowing. ${ }^{17,19}$ It was also reported that the Matrix $\mathrm{P}^{\mathrm{TM}}$ Plus valve displayed early obstruction following implantation in pediatric patients. ${ }^{20}$ It is likely that these problems were due to the glutaraldehyde fixed pericardial patches used in the grafts. ${ }^{20}$ The latest version of the valve, the Matrix P Plus $\mathrm{N}$, has been decribed as a cell-free valve incorporating a cell free unfixed pericardial patch.

The evidence indicates that it is therefore of paramount importance that any future acellular porcine pulmonary valves developed for clinical use are devoid of cells, residual $\alpha$-gal and DNA. This study presents the development of a process to produce acellular porcine pulmonary valve conduits, which eliminates $\alpha$-gal and effectively removes cells and DNA from all regions while retaining the biomechanical and pulsatile flow properties of the conduit.

\section{Materials and Methods}

\section{Tissue procurement}

Porcine hearts from Large White pigs (24 to 26 weeks old) were obtained from a local abattoir within $4 \mathrm{~h}$ of slaughter. The pulmonary heart valve together with pulmonary artery and a myocardium skirt (from the right ventricle) were separated from the heart. Excess fat and connective tissue were removed and the adventitial surface of the pulmonary artery was scraped using a scalpel blade prior to washing in phosphate-buffered saline (PBS; Oxoid). The porcine pulmonary roots were either used fresh, or wiped dry and wrapped in PBS-moistened filter paper in a sealed container and stored at $-20^{\circ} \mathrm{C}$ as the first step of decellularization process.

\section{Decellularization}

The decellularization process was modified from Wilcox et al $^{21}$ for porcine aortic roots. Pulmonary roots were defrosted at $37^{\circ} \mathrm{C}$ for $30 \mathrm{~min}$ and disinfected with antibiotics
(100 U.mL ${ }^{-1}$ penicillin [Invitrogen], $100 \mu \mathrm{g} \cdot \mathrm{mL}^{-1}$ streptomycin [Invitrogen], and $50 \mu \mathrm{g} \cdot \mathrm{mL}^{-1}$ gentamicin [SigmaAldrich] in PBS) for $16-17 \mathrm{~h}$ at $4^{\circ} \mathrm{C}$. The leaflets were masked using cotton wool soaked with $50 \%$ (v/v) fetal bovine serum (FBS; Biosera) in PBS prior to trypsin treatment, which involved brushing trypsin treatment paste $\left(1.125 \times 10^{4} \mathrm{U} . \mathrm{mL}^{-1}\right.$ trypsin [Sigma-Aldrich] in $0.5 \%(\mathrm{w} / \mathrm{v})$ agarose [Invitrogen] in PBS) on the adventitial surface of the artery and myocardium skirt and incubating at $37^{\circ} \mathrm{C}$ for $4 \mathrm{~h}$. The tissue was rinsed in trypsin inhibitor solution (trypsin inhibitor [Sigma-Aldrich] $675 \mathrm{U}^{\mathrm{mL}}{ }^{-1}, 0.1 \%$ [v/v] EDTA [VWR International], and $10 \mathrm{KIU}$ aprotinin [Mayfair House] in PBS) thrice for $30 \mathrm{~min}$ at $37^{\circ} \mathrm{C}$. The roots were then sequentially washed in hypotonic Tris buffer (HTB; $10 \mathrm{mM}$ Tris [Sigma-Aldrich] 0.1\% [v/v] EDTA, and $10 \mathrm{KIU}$ aprotinin, $\mathrm{pH} 8.0$ ) at $40-45^{\circ} \mathrm{C}$ for $24 \mathrm{~h} ; 0.1 \%$ (v/v) SDS (Sigma-Aldrich) in $\mathrm{HTB}$ at $40-45^{\circ} \mathrm{C}$ for $24 \mathrm{~h}$; nuclease (50 U.mL ${ }^{-1}$ DNase [Sigma-Aldrich], $1 \mathrm{U}^{-\mathrm{mL}^{-1}}$ RNase [Sigma-Aldrich], $50 \mathrm{mM}$ Tris $\mathrm{pH} 7.5$, and $10 \mathrm{mM}$ magnesium chloride [Thermo Fisher Scientific Ltd.]) at $37^{\circ} \mathrm{C}$ for $3 \mathrm{~h}$ twice; hypertonic buffer (1.5 $\mathrm{M}$ sodium chloride [Thermo Fisher Scientific Ltd.] and $50 \mathrm{mM}$ Tris, $\mathrm{pH} 7.5$ ) for $24 \mathrm{~h}$ at $40-45^{\circ} \mathrm{C}$ and decontaminated in $0.1 \%(\mathrm{v} / \mathrm{v})$ peracetic acid (Sigma; $\mathrm{pH}$ 6.0) in PBS for $3 \mathrm{~h}$ at $37^{\circ} \mathrm{C}$. Final washes in PBS were carried out aseptically and included three $30 \mathrm{~min}$ washes at $40-45^{\circ} \mathrm{C}$, three $24 \mathrm{~h}$ washes at $4^{\circ} \mathrm{C}$, and a $66 \mathrm{~h}$ wash at $4{ }^{\circ} \mathrm{C}$.

\section{Histology}

Fresh and decellularized specimens $(n=6)$ were fixed in $10 \%(\mathrm{v} / \mathrm{v})$ neutral buffered formalin (NBF) for $24 \mathrm{~h}$, dehydrated, and embedded in paraffin wax. Serial sections $(10 \mu \mathrm{m})$ were stained with hematoxylin and eosin $(\mathrm{H} \& \mathrm{E})$, picrosirius red/Millers elastin (to visualize collagen and elastin), Masson's trichrome (collagen and muscle), and Alcian blue (glycosaminoglycans, GAGs) using standard histological methods. Cell nuclei were visualized using Hoechst dye (Sigma-Aldrich). Images were captured using an upright Olympus BX51 light microscope, incorporating an Olympus XC50 digital camera, which was controlled by the Cell B software (Olympus ${ }^{\circledR}$ ).

\section{Immunohistochemistry}

Fresh and decellularized tissue specimens $(n=6)$ were fixed in $10 \%(\mathrm{v} / \mathrm{v}) \mathrm{NBF}$ or zinc fixative for $24 \mathrm{~h}$. Monoclonal antibodies against vimentin (Novacastra), von Willebrand factor (vWF; DAKO), fibronectin (DAKO), and collagen IV (DAKO) were used. Immunolabeling was carried out using an Ultravision detection system (Thermo Scientific). Antigen retrieval was employed using trypsin (for fibronectin) or citric acid (for vWF, vimentin, collagen IV). Hydrogen peroxide (Sigma) was used to block endogenous peroxidase. Fresh porcine skin was used as a positive control, whereas isotype control antibodies (IgG1 and $\operatorname{IgG} 2 \mathrm{a}$, both from DAKO) and omission of the primary antibody served as negative controls. Images were captured as described above.

\section{Transmission electron microscopy (TEM)}

Fresh and decellularized leaflet specimens $(n=2)$ were fixed and embedded as described by Mirsadraee et al. ${ }^{22}$ 
Sections were examined using a Jeol JEM 1400 transmission electron microscope and images were photographed.

\section{DNA extraction}

Total DNA was extracted from fresh and decellularized tissues $(n=6)$ using a DNeasy blood and tissue kit from Qiagen. Four regions of the pulmonary roots were assayed for total DNA content: leaflet, pulmonary artery, myocardium, and leaflet connection. Finely macerated tissue ( $\sim 5$ to $20 \mathrm{mg}$ dry weight fresh tissue or $\sim 11$ to $35 \mathrm{mg}$ dry weight decellularized tissue) was digested using proteinase $\mathrm{K}$ at $56^{\circ} \mathrm{C}$ for 16h. RNAse was used to remove any RNA present within the samples. The samples were washed by centrifugation to remove contaminating matter. Finally, the DNA was eluted into Eppendorf tubes and quantified using a NanoDrop spectrophotometer at $260 \mathrm{~nm}$ (Thermo Fisher Scientific)

\section{Polymerase chain reaction}

The presence of genes for glyceraldehyde 3-phosphate dehydrogenase (GAPDH), swine leukocyte antigen 2 (SLA2), $\beta$ 2-microglobulin, and $\beta$-actin in DNA extracted from the fresh and decellularized porcine pulmonary root tissue samples was assessed by polymerase chain reaction (PCR). Primers were custom-made by Sigma. PCR master mix $(2 \times$; Fermentas) and nuclease-free water (Fermentas) were used. For each round of reaction, a no-template control was included. PCR products were analyzed using $4 \%(\mathrm{w} / \mathrm{v})$ agarose E-gels (Invitrogen) together with an E-gel PowerBase system (Invitrogen). The sizes of PCR products were identified by running a Quick-Load ${ }^{\circledR}$ PCR marker (Biolabs) in parallel. Images were taken by exposing the gels under UV light in a Kodak Gel Logic 1500 system (Eastman Kodak).

\section{Biochemical assays}

Biochemical assays were performed on fresh $(n=6)$ and decellularized $(n=6)$ porcine pulmonary leaflets and pulmonary artery wall samples, which had been lyophilized to constant weight.

Hydroxyproline assay. Samples were hydrolyzed in $6 \mathrm{M}$ hydrochloric acid for $6 \mathrm{~h}$ at $120^{\circ} \mathrm{C}$, at $15 \mathrm{lb}_{\text {s.sin }}{ }^{-1}$ and neutralized with $6 \mathrm{M}$ sodium hydroxide. The hydroxyproline assay was performed as described by Edwards and O'Brien. ${ }^{23}$ The hydroxyproline content was determined by interpolation from a trans-4-hydroxy-L-proline standard curve.

Denatured collagen assay. The assay was performed as described by Bank et al. ${ }^{24}$ Samples were treated with $5 \mathrm{mg} \cdot \mathrm{mL}^{-1} \alpha$-chymotrypsin (Sigma) in $0.1 \mathrm{M}$ tris buffer containing $2.5 \mathrm{mM}$ calcium chloride for $24 \mathrm{~h}$ at $30^{\circ} \mathrm{C}$. The samples were centrifuged at $600 \mathrm{~g}$ for $10 \mathrm{~min}$. The supernatant was hydrolyzed, neutralized, and the hydroxyproline content was determined as described above.

GAG assay. Samples were digested by incubating with $5 \mathrm{~mL}$ of $50 \mathrm{U} \cdot \mathrm{mL}^{-1}$ papain (Sigma-Aldrich) solution for $48 \mathrm{~h}$ at $60^{\circ} \mathrm{C}$. The diluted tissue digestion solution $(40 \mu \mathrm{L})$ was mixed with $250 \mu \mathrm{L}$ DMB dye solution $(1.6 \%$ [w/v] 1,9 dimethylene blue [Sigma-Aldrich], 0.5\% [v/v] ethanol [VWR International], $0.2 \%[\mathrm{v} / \mathrm{v}]$ formic acid [Sigma-
Aldrich], $0.2 \%$ [w/v] sodium formate [VWR International], $\mathrm{pH}$ 3.0), and the optical densities were measured using a microplate spectrophotometer at $525 \mathrm{~nm}$. The GAG content was determined by interpolation from a chondroitin sulphate B (Sigma-Aldrich) standard curve.

\section{Determination of the presence of xenoantigen $\alpha$-gal}

Zinc fixed tissue sections $(10 \mu \mathrm{m})$ were labeled with anti galactose- $\alpha$-1,3-galactose ( $\alpha$-gal; Alexis Biochemicals) at a concentration of $1 \mathrm{mg} \cdot \mathrm{mL}^{-1}$ using the Ultravision Detection system. An antigen unmask solution (Vector) was used for antigen retrieval, and hydrogen peroxide (Sigma) was used to block endogenous peroxidase. Porcine artery served as the positive control tissue. An IgM isotype control and the absence of primary antibody were used as negative controls. An antibody absorption assay was employed on fresh, decellularized, and $\alpha$-galactosidase-treated tissue to quantitate the $\alpha$-gal. Tissue samples $(100 \mathrm{mg} ; n=6)$ were analyzed as described by Stapleton et al. $^{25}$

\section{Biomechanical assessment}

Uniaxial tensile loading to failure. Leaflet specimens measuring $6 \times 3 \mathrm{~mm}$ (circumferential and radial directions; minimum six per group), and circumferential or axial wall specimens measuring $10 \times 5 \mathrm{~mm}$ (minimum six per group) were isolated and their thickness was measured using a Mitutoyo thickness gauge. The specimens were then mounted at a relaxed state onto a purpose-built clamping holder, which was then mounted into a Shimazu tensile testing machine. The samples were preloaded to $0.02 \mathrm{~N}$ and were then loaded to failure at a speed of $10 \mathrm{~mm}$ per minute. Failure was taken as the first decrease in the recorded load during extension. The real-time load and extension data were recorded during tests. The stress-strain behavior of the specimens was analyzed in terms of the elastin phase slope, collagen phase slope, transition stress, transition strain, failure stress, and the failure strain as described by Korossis et $a .^{26}$

Pulsatile flow testing. The pulmonary root hydrodynamics was evaluated using near physiological pulsatile flow testing. The flow simulator has been described previously. ${ }^{27}$ It mimicked the right heart and was controlled and monitored by the ViviTest software (Vivitro Systems, Inc.). The simulator was set up as described by Korossis et al. ${ }^{28}$ Fresh and decellularized porcine pulmonary roots $(n=6)$ were tested under three different pulsatile flow conditions (Table 1). The pressures applied under each condition were the minimum pressures that could be achieved by the simulator at the required cardiac output. The hydrodynamic performance of the pulmonary roots was assessed by mean pressure drop across the valves $(\Delta \mathrm{p})$, the root mean square (RMS) forward flow, and the valve effective orifice area (EOA), which was calculated according to the experimental formula: ${ }^{29}$

$$
\mathrm{EOA}=\frac{\mathrm{Q}_{\mathrm{RMS}}}{51.6 \times \Delta \mathrm{p}}
$$

The leaflet kinematics was assessed during a complete cardiac cycle under pulsatile flow condition 2 (Table 1). The 
Table 1. Flow Conditions Used In the Hydrodynamic Testing

\begin{tabular}{|c|c|c|c|c|}
\hline Condition & $\begin{array}{l}\text { Heart } \\
\text { rate } \\
\text { (bpm) }\end{array}$ & $\begin{array}{c}\text { Stroke } \\
\text { volume } \\
(\mathrm{mL})\end{array}$ & $\begin{array}{c}\text { Cardiac } \\
\text { output } \\
(\text { l.min } \\
-1)\end{array}$ & $\begin{array}{c}\text { Pulmonary } \\
\text { pressure } \\
\text { (mmHg) }\end{array}$ \\
\hline 1 & 60 & 60 & 3.60 & $35 / 5$ \\
\hline & 72 & 70 & 5.04 & $45 / 10$ \\
\hline 3 & 80 & 70 & 5.60 & $50 / 10$ \\
\hline
\end{tabular}

leaflet motion was recorded using a high speed camera (Redlake ${ }^{\circledR}$ Motion Scope, Model PCI 1000S) at a recording rate of 250 frames per second. The phase durations were determined by counting the number of video frames between the reference points (start opening, fully open, start closing, fully closed, and start opening) and multiplying it by the frame acquisition interval $(4 \mathrm{~ms})$.

\section{In vitro biocompatibility assays}

Cell culture. 3T3 murine fibroblasts (ECACC) were cultured in Dulbecco's modified Eagle's medium (DMEM) containing $10 \% \quad(\mathrm{v} / \mathrm{v})$ FBS, $100 \mathrm{U} \cdot \mathrm{mL}^{-1}$ penicillin, $100 \mu \mathrm{g} . \mathrm{mL}^{-1}$ streptomycin, and $100 \mathrm{mM}$ L-glutamine (Lonza) at $37^{\circ} \mathrm{C}$ in $5 \% \mathrm{CO}_{2}(\mathrm{v} / \mathrm{v})$ in air.

BHK baby hamster kidney cells (ECACC) were cultured in Glasgow's modified Eagle's medium (GMEM) containing 5\% (v/v) FBS, 10\% (v/v) tryptose phosphate broth (Oxoid) at $37^{\circ} \mathrm{C}$ in $100 \mathrm{U} \cdot \mathrm{mL}^{-1}$ penicillin, $100 \mu \mathrm{g} \cdot \mathrm{mL}^{-1}$ streptomycin, and $100 \mathrm{mM} \mathrm{L-glutamine,} 5 \% \mathrm{CO}_{2}(\mathrm{v} / \mathrm{v})$ in air.

Contact cytotoxicity assay. Decellularized porcine pulmonary leaflet samples $\left(5 \mathrm{~mm}^{2}, n=6\right)$ were attached to the center of the wells of a six-well culture plate using collagen gel extracted from rat tail tendons. Decellularized pulmonary artery samples $\left(5 \mathrm{~mm}^{2}, n=6\right)$ were attached to the center of the wells using steri strips. Cyanoacrylate glue was used as positive control, and collagen gel or steri strips alone were used as the negative control. 3T3 or BHK cells were seeded into each well at a density that allowed $80 \%$ confluence after cell seeding. Plates were incubated at $37^{\circ} \mathrm{C}$ in $5 \%(\mathrm{v} / \mathrm{v}) \mathrm{CO}_{2}$ in air for $48 \mathrm{~h}$. The cells were fixed with $10 \%$ (v/v) NBF for $10 \mathrm{~min}$ prior to staining with Giemsa solution (VWR International) for $5 \mathrm{~min}$. The culture wells were carefully rinsed with distilled water until water ran clear and air-dried before being examined under a brightfield microscope for cell morphology and distribution.

Extract cytotoxicity assay. Decellularized porcine pulmonary artery samples $(n=6)$ were finely minced, weighed, and incubated in DMEM or GMEM $(1 \mathrm{~mL}$ medium per $100 \mathrm{mg}$ tissue) in sterile Eppendorf tubes for $72 \mathrm{~h}$ with agitation. Following incubation, the extracts were centrifuged at $15,000 \mathrm{~g}$ for $15 \mathrm{~min}$ and the supernatant was collected. Cells (3T3 and BHK) were seeded into a 96-well plate at 10,000 cells per well, and incubated overnight at $37^{\circ} \mathrm{C}$ in $5 \%(\mathrm{v} / \mathrm{v}) \mathrm{CO}_{2}$ in air. The cell culture medium was removed and $100 \mu \mathrm{L}$ of fresh culture medium and $100 \mu \mathrm{L}$ of the tissue extract were added to each well. The cells were incubated with $200 \mu \mathrm{L}$ of $40 \%$ (v/v) dimethyl sulfoxide (DMSO; Sigma Aldrich) in DMEM or GMEM as positive controls. The negative control consisted of $200 \mu \mathrm{L}$ cell culture medium alone. The cells were incubated at $37^{\circ} \mathrm{C}$ in $5 \%(\mathrm{v} / \mathrm{v})$ $\mathrm{CO}_{2}$ in air for $24 \mathrm{~h}$. The cell viability [relative cellular adenosine triphosphate (ATP) content] was determined using the ATP Lite- $\mathrm{M}^{\circledR}$ assay (Packard) as per the manufacturer's instruction. Data were recorded as luminescent counts per second.
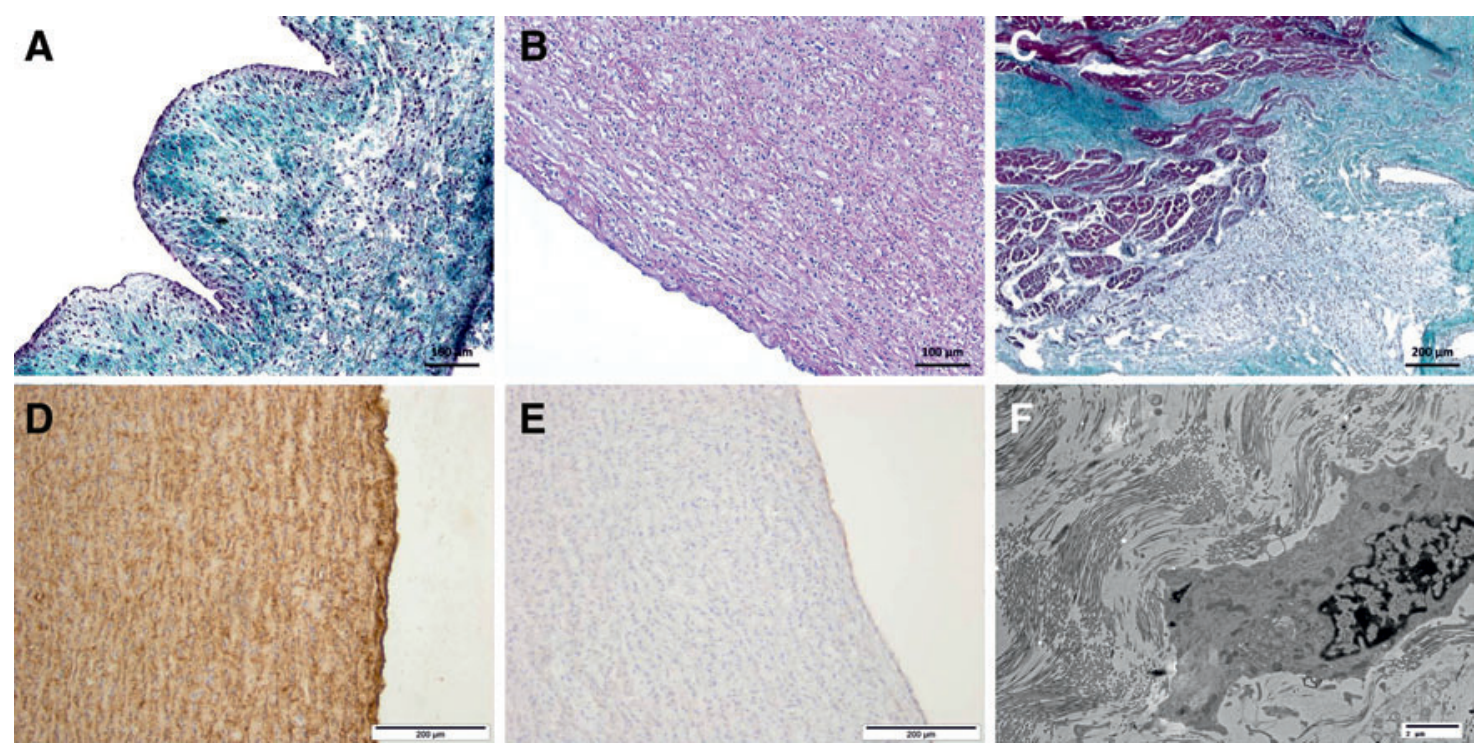

FIG. 1. Histological and immunohistochemical images of fresh porcine pulmonary leaflets and pulmonary arteries. (A) Fresh pulmonary leaflet stained with Masson's trichrome, $100 \times ;(\mathbf{B})$ Fresh pulmonary artery stained with hematoxylin and eosin $(\mathrm{H} \& \mathrm{E}), 100 \times$; (C) Fresh connection stained with Masson's trichrome, $50 \times$; (D) Fresh pulmonary artery stained for fibronectin, $100 \times$; (E) Fresh pulmonary artery stained for collagen type IV, $100 \times$; (F) Transmission electron micrograph of fresh pulmonary leaflet, $1500 \times$. Color images available online at www.liebertpub.com/tea 

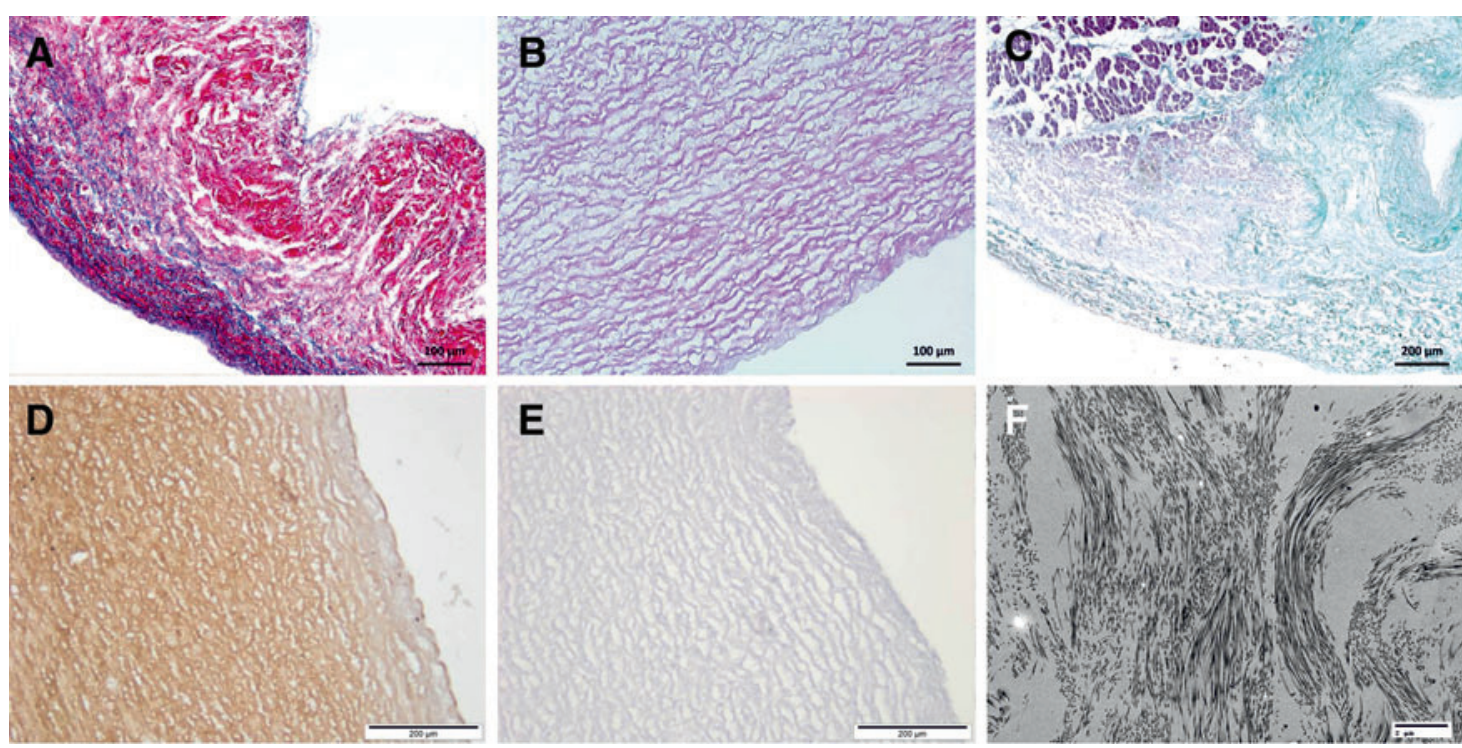

FIG. 2. Histological and immunohistochemical images of acellular porcine pulmonary leaflets and pulmonary arteries. (A) Acellular pulmonary leaflet stained with picrosirius red/Miller's elastin, $100 \times$; (B) Acellular pulmonary artery stained with H\&E; (C) Acellular connection stained with Masson's trichrome, 50×; (D) Acellular pulmonary artery stained for fibronectin, $100 \times$; (E) Acellular pulmonary artery stained for collagen type IV, 100×; (F) Transmission electron micrograph of acellular pulmonary leaflet, $1500 \times$. Color images available online at www.liebertpub.com/tea

\section{Data analysis}

All numerical data were analyzed using Microsoft Excel (Version 2003 or 2007), and all data were presented as mean $\pm 95 \%$ confidence intervals (CI). The Student's $t$-test was used for comparison of two group means. One-way ANOVA followed by calculation of the minimum significance difference (MSD) by the T-method at the $95 \% \mathrm{CI}$, was used to analyze data from more than two groups. Individual differences between group means were identified by comparing the difference between two group means to the MSD. ${ }^{30}$

\section{Results}

\section{Histological analysis}

Histological analysis of the native porcine root using a range of staining techniques revealed the cellular distribution in the tissue and characteristic tri-laminar structure of the pulmonary valve leaflets, the structure of the leaflet connection, and collagen arrangement in the pulmonary artery wall. Representative images are shown in Figure 1AC. The connection is the region where the root of the pulmonary leaflet attaches to the myocardium and the pulmonary artery and both leaflet tissue and myocardium tissue were recognizable in the image of the connection area (Fig. 1C). Cells throughout the fresh porcine pulmonary root were positive for vimentin (data not shown) and the arterial matrix was rich in fibronectin (Fig. 1D). The endothelial layer was positive for vWF (data not shown). Collagen type IV staining was found in the region of the basement membrane (Fig. 1E). There was no evidence of cells throughout the acellular pulmonary root, whereas the tissue histoarchitecture was well preserved following decellularization (Fig. 2A-C). Hoechst staining was negative in the acellular tissue (data not shown). Staining for vimentin, vWF, and collagen type IV was negative in acellular tissue samples (Fig. 2E) and acellular pulmonary artery was less intensely stained for fibronectin (Fig. 2D), particularly in regions close to the surface compared to the fresh tissue (Fig. 1D). No obvious difference in the collagen fiber distribution between the fresh and acellular leaflets was observed by transmission electron microscopy (TEM) (Figs. $1 \mathrm{~F}$ and $2 \mathrm{~F}$ ).

\section{DNA content}

Total DNA content was reduced to less than 100 ng.mg ${ }^{-1}$ tissue dry weight in all regions of the acellular porcine pulmonary root (Table 2). The DNA content of the acellular tissue was less than $4 \%$ of the DNA content of fresh tissue in all regions.

\section{Polymerase chain reaction}

GAPDH, SLA-2, $\beta 2$ microglobulin, and $\beta$-actin gene fragments were positively amplified from fresh tissue DNA template, whereas no PCR product was detected in the acellular samples or the blank reactions (Fig. 3).

Table 2. DNA Content of Fresh and Acellular Porcine Pulmonary Roots

\begin{tabular}{lcccc}
\hline & Leaflets & Wall & Myocardium & Connection \\
\hline Fresh $\left(\right.$ ng. $\left.\mathrm{mg}^{-1}\right)$ & $7190 \pm 210$ & $4060 \pm 710$ & $4290 \pm 620$ & $2840 \pm 850$ \\
Acellular $\left(\mathrm{ng}_{\mathrm{mg}} \mathrm{mg}^{-1}\right)$ & $60.7 \pm 20.0$ & $36.5 \pm 9.1$ & $53.6 \pm 13.9$ & $95.7 \pm 15.9$ \\
\hline
\end{tabular}

Data are expressed as the mean $(n=6) \pm 95 \%$ confidence limits. $p<0.05$ for all acellular versus fresh. 

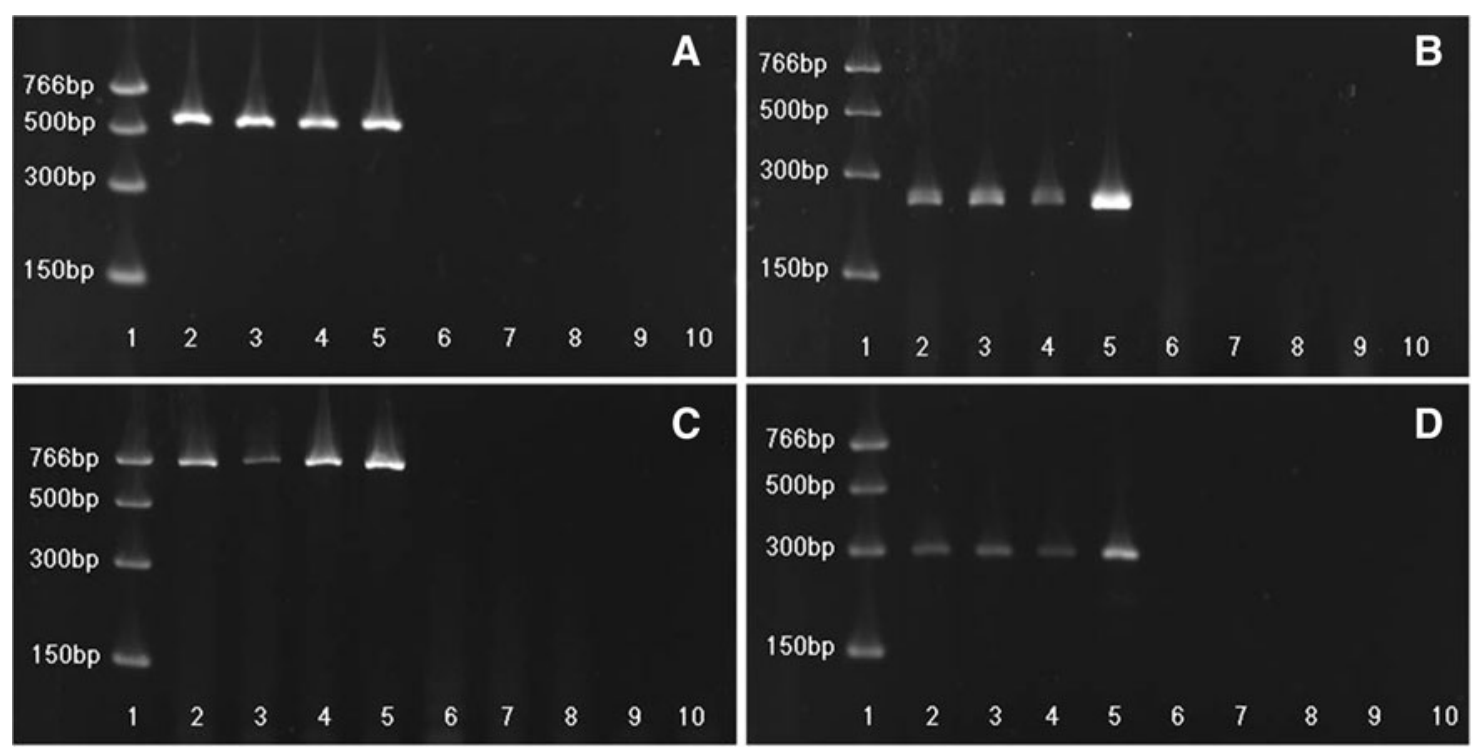

FIG. 3. PCR products on a 4\% E gel for GAPDH (A), SLA-2 (B), $\beta$ 2-microglobulin (C), and $\beta$-actin (D). Lane 1: QuickLoad $^{\circledR}$ PCR marker (Biolabs); Lane 2-5: fresh porcine pulmonary leaflet, fresh porcine pulmonary artery, fresh porcine myocardium, fresh porcine pulmonary leaflet connection; a band is present on the gel at around $600 \mathrm{bp}(\mathbf{A}), 250 \mathrm{bp}(\mathbf{B})$, $760 \mathrm{bp}$ (C), and $300 \mathrm{bp}$ (D). Lane 6-9: acellular porcine pulmonary leaflet, acellular porcine pulmonary artery, acellular porcine myocardium, acellular porcine pulmonary leaflet connection; no band is present on the gel. Lane 10: blank; no band is present on the gel.

\section{Biochemical assays}

The biochemical assay results are presented in Table 3. The relative hydroxyproline content in the tissue was significantly elevated after decellularization $(p<0.05)$. No significant difference was found between fresh and acellular pulmonary leaflet denatured collagen content $(p>0.05)$. However, a small but significantly higher level of denatured collagen was revealed in the pulmonary artery following decellularization $(p<0.05)$. Moreover, there was a significant reduction in the GAG content of the acellular tissue compared with the fresh $(p<0.05)$.

\section{Determination of the presence of xenoantigen $\alpha$-gal}

Fresh pulmonary leaflets and arteries were positive for $\alpha$ gal (Fig. 4A, C). The $\alpha$-gal was mainly distributed on the endothelial layer and spongiosa layer in the fresh pulmonary leaflets (Fig. 4A). No evidence of positive staining was observed throughout the acellular porcine pulmonary roots (Fig. 4B, D).

Fresh porcine pulmonary arteries absorbed anti $\alpha$-gal antibodies. Treatment of the tissue with $\alpha$-galactosidase abrogated antibody binding. The levels of anti $\alpha$-gal anti- bodies absorbed by the acellular tissue were not significantly different from the $\alpha$-galactosidase-treated fresh tissue or no tissue control indicating that the acellular pulmonary arteries did not contain $\alpha$-gal, and they were comparable to the tissue from which the $\alpha$-gal had been enzymatically removed (Fig. 5).

\section{Biomechanical assessment}

Uniaxial tensile loading to failure. A representative mean stress-strain behavior curve for the fresh and acellular pulmonary wall in the circumferential direction is shown in Figure 6. There was no significant difference in the tensile properties between acellular and fresh pulmonary leaflets. Fresh and acellular pulmonary arteries also showed no significant difference in their tensile properties, with the exception of a significant increase $(p<0.05)$ in the elastin phase slope of the acellular pulmonary artery in both directions (Table 4).

Hydrodynamic assessment. The fresh and acellular groups demonstrated similar hydrodynamic performance under all three test conditions listed in Table 1 as shown in

Table 3. Biochemical Characterization of Fresh and Acellular Porcine Pulmonary Roots

\begin{tabular}{lccrr}
\hline Assay & $\begin{array}{c}\text { Fresh leaflets } \\
\left(\mu g . \mathrm{mg}^{-1}\right)\end{array}$ & $\begin{array}{c}\text { Acellular leaflets } \\
\left(\mu g . \mathrm{mg}^{-1}\right)\end{array}$ & $\begin{array}{c}\text { Fresh wall } \\
\left(\mu \mathrm{mg}^{-1}\right)\end{array}$ & $\begin{array}{c}\text { Acellular wall } \\
\left(\mu g . \mathrm{mg}^{-1}\right)\end{array}$ \\
\hline Hydroxyproline & $70.7 \pm 6.2$ & $133.8 \pm 17.5^{\mathrm{a}}$ & $36.3 \pm 3.0$ & $54.3 \pm 3.0^{\mathrm{a}}$ \\
Denatured collagen & $3.5 \pm 0.6$ & $2.8 \pm 0.7$ & $2.8 \pm 0.3$ & $4.5 \pm 0.3^{\mathrm{a}}$ \\
GAG & $20.2 \pm 0.6$ & $4.0 \pm 0.4^{\mathrm{a}}$ & $9.7 \pm 1.2$ & $4.3 \pm 0.8^{\mathrm{a}}$ \\
\hline
\end{tabular}

Data are expressed as the mean $(n=6) \pm 95 \%$ confidence limits.

${ }^{a}$ Indicates $p<0.05$ acellular versus fresh. 

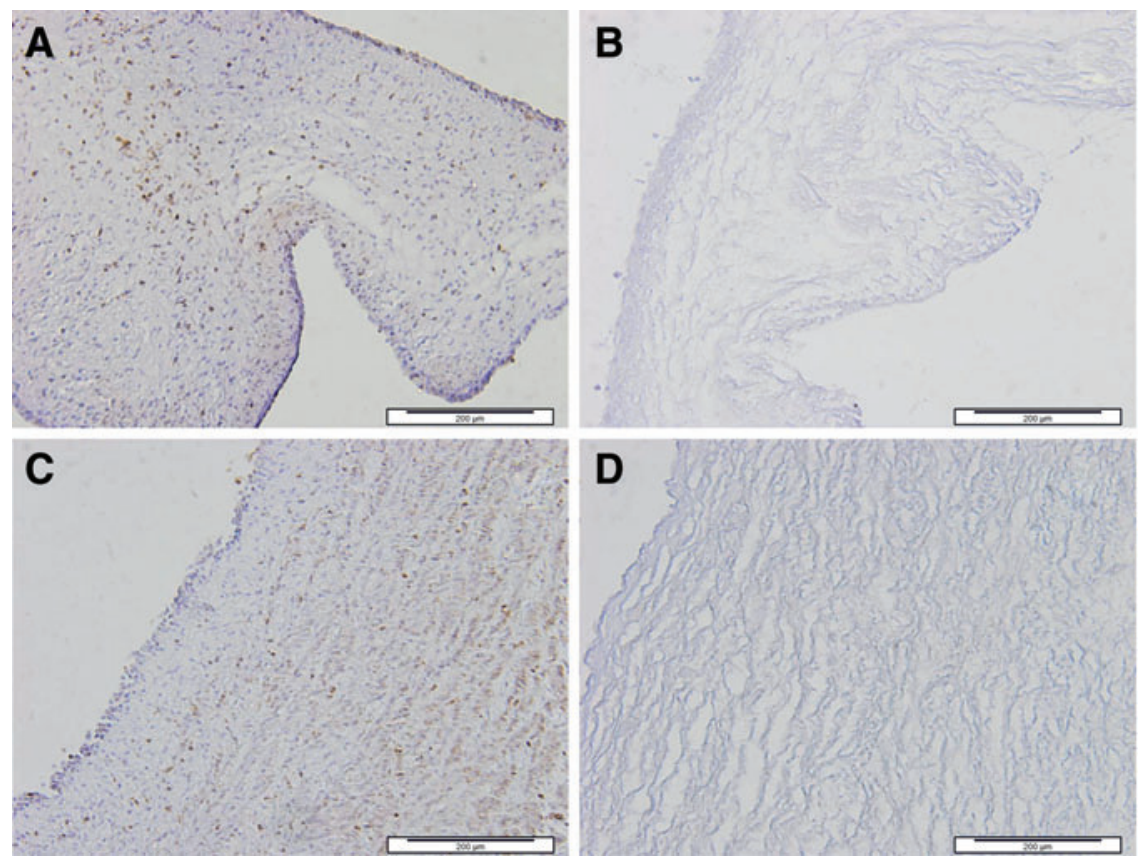

FIG. 4. Localization of $\alpha$-gal in fresh and acellular porcine pulmonary leaflets and arteries. (A) Fresh pulmonary leaflet; (B) Acellular pulmonary valve leaflet; (C) Fresh pulmonary artery; (D) Acellular pulmonary artery. All images were $100 \times$ magnification. Color images available online at www.liebertpub.com/tea

Figure 7A. There was no significant difference of the average EOA (Fig. 7B) between fresh and decellularized groups in any of the test conditions used $(p>0.05)$.

Leaflet kinematics. Both fresh and decellularized valves demonstrated synchronous opening and closing leaflet motion (Fig. 8A). During opening, all fresh and decellularized roots demonstrated the same stellate, triangular, and circular configurations as previously described for the semilunar valves. $^{31,32}$ All valves demonstrated fully closed leaflet configurations with no visible leakage orifices or coaptation flaws during diastole. The decellularized valve leaflets were more transparent than the fresh leaflets. The durations of the

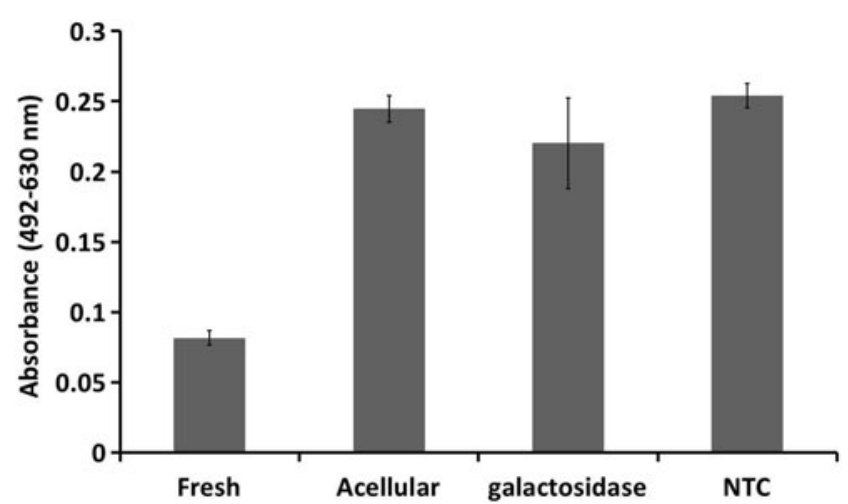

FIG. 5. Antibody absorption assay for $\alpha$-gal. Data show the remaining anti $\alpha$-gal antibodies following absorption with fresh, acellular, and galactosidase-treated acellular pulmonary arteries. NTC: no tissue control. Data are represented as the mean $(n=6) \pm 96 \%$ CI. Data were analyzed using one-way ANOVA followed by calculation of the MSD by the T-method $(p<0.05)$. There were no significant differences except when comparing the fresh tissue with all of the other groups. opening, open, closing, and closed phases averaged over the number of roots studied are shown in Figure 8. The opening phase duration of the decellularized group was considerably longer than that of the fresh roots, and the mean of the closed phase duration of the decellularized roots was much shorter than that of the fresh roots. However, no statistically significant difference was observed between the fresh and decellularized groups in any of the phases studied.

\section{In vitro biocompatibility assays}

Contact cytotoxicity assay. Microscopic images showed that $3 \mathrm{~T} 3$ cells (Fig. 9) and BHK cells (data not shown) grew up to and in contact with the acellular pulmonary leaflets and artery wall tissue with no change in morphology compared to the controls. Collagen or steri strip alone (negative controls) showed no signs of cytotoxicity (data not shown). When cultured with cyanoacrylate glue, no evidence of cells was found in a circular area around the adhesive (data not shown).

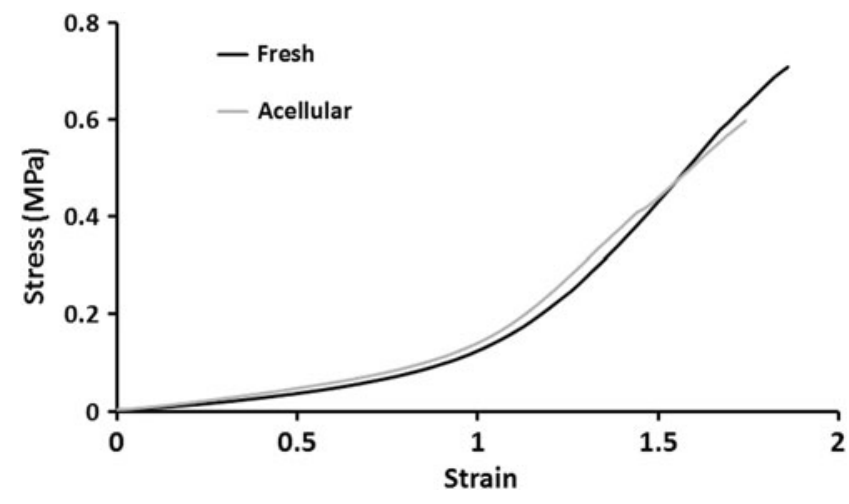

FIG. 6. Mean stress-strain behavior for the fresh $(n=6)$ and acellular $(n=6)$ circumferential pulmonary wall groups. 
Table 4. Elastin (El-E) and Collagen (COL-E) Phase Slopes, Ultimate Tensile Strength ( $\left.\varepsilon_{\text {Uts }}\right)$, and Failure $\operatorname{Strain}\left(\varepsilon_{\text {Uts }}\right)$ Following Uniaxial Tensile Testing of Fresh and Acellular Porcine Pulmonary Leaflets (Circumferential and Radial Directions) and Arteries (Circumferential and Axial Directions)

\begin{tabular}{lccrr}
\hline Assay & $E L-E(\mathrm{kPa})$ & Coll-E $(\mathrm{MPa})$ & $\sigma_{U T S}(\mathrm{MPa})$ & ${ }^{\varepsilon_{U T S}}(\%)$ \\
\hline Fresh leaflet (C) & $755 \pm 286$ & $15.3 \pm 3.6$ & $5.27 \pm 1.59$ & $58.2 \pm 14.3$ \\
Acellular leaflet (C) & $763 \pm 219$ & $21.5 \pm 9.3$ & $5.96 \pm 1.55$ & $59.4 \pm 11.5$ \\
Fresh leaflet (R) & $342 \pm 62$ & $1.19 \pm 0.24$ & $0.51 \pm 0.10$ & $67.2 \pm 14.2$ \\
Acellular leaflet (R) & $352 \pm 56$ & $1.29 \pm 0.27$ & $0.64 \pm 0.05$ & $60.6 \pm 14.8$ \\
Fresh wall (C) & $44 \pm 5$ & $0.79 \pm 0.23$ & 0.590 .08 & $208.8 \pm 24.4$ \\
Acellular wall (C) & $55 \pm 4^{\mathrm{a}}$ & $0.85 \pm 0.12$ & $0.42 \pm 0.04$ & $177.0 \pm 17.9$ \\
Fresh wall (A) & $31 \pm 4$ & $0.51 \pm 0.10$ & $0.37 \pm 0.04$ & $209.7 \pm 25.4$ \\
Acellular wall (A) & $52 \pm 8^{\mathrm{a}}$ & $0.46 \pm 0.10$ & $180.0 \pm 12.0$
\end{tabular}

Data are expressed as the mean $(n=6) \pm 95 \%$ confidence limits. Data were analyzed by ANOVA, which revealed significant difference in elastin slope between fresh and decellularized tissue $\left({ }^{\mathrm{a}}\right)$.

$\mathrm{C}$, circumferential direction; R, radial direction; A, axial direction.

Extract cytotoxicity assay. ATP levels were significantly lower in the positive control $(p<0.05)$ compared with the negative control for both $3 \mathrm{~T} 3$ and BHK cells (Fig. 10). The mean ATP content of the cells cultured with the six acellular porcine pulmonary artery extracts were not significantly different from the negative control for both cell types. When
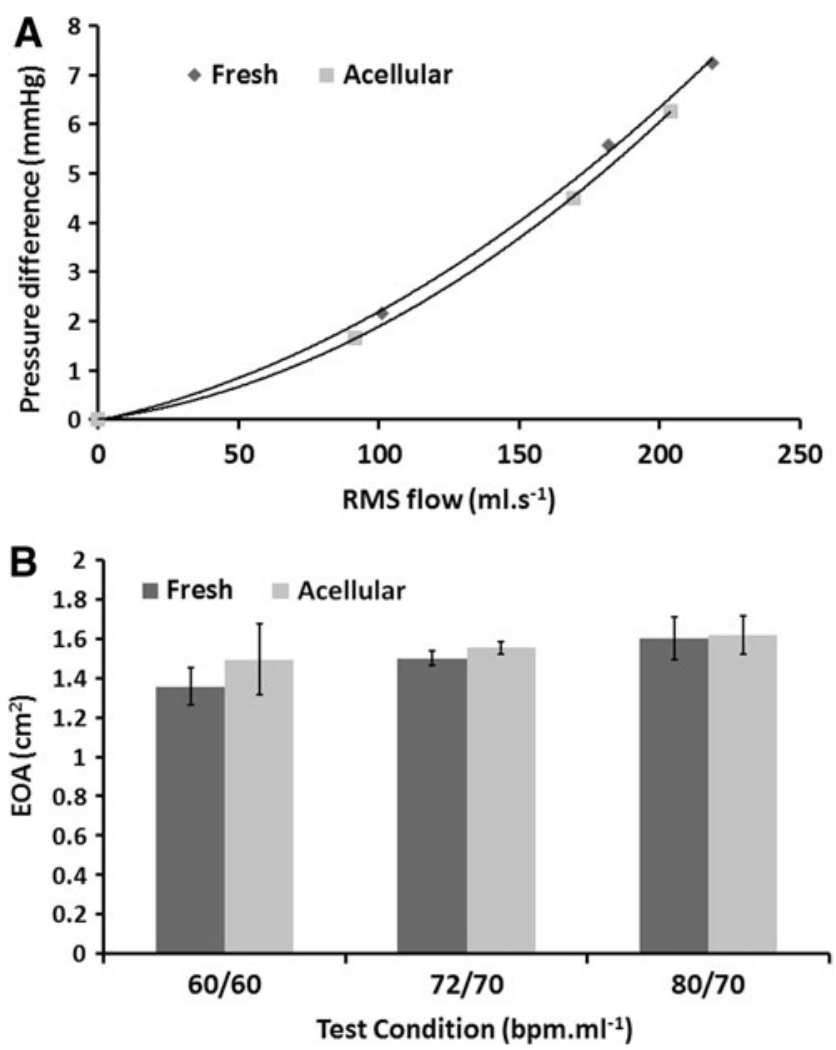

FIG. 7. Hydrodynamic assessment of fresh and acellular pulmonary roots. (A) Average $\Delta \mathrm{p}$ versus average RMS flow for the fresh $(n=6)$ and acellular $(n=6)$ groups at the three test conditions (Table 1). (B) Average EOA for the fresh $(n=6)$ and acellular $(n=6)$ porcine pulmonary roots at each test conditions (Table 1). The error bars indicate the $95 \%$ confidence intervals (CIs). No significant differences were found between the two groups. comparing the ATP level of cells cultured with individual decellularized pulmonary roots to the negative control, a significant increase in ATP level was observed in one out of six acellular pulmonary artery extracts cultured with both cell types.

\section{Discussion}

Decellularization was performed through modification of a previously developed method for porcine aortic valve conduit. $^{21}$ The process utilized $1.25 \%(\mathrm{w} / \mathrm{v})$ trypsin digestion of the adventitial surface of the scraped pulmonary artery, washing in $0.1 \%(\mathrm{w} / \mathrm{v})$ SDS-hypotonic buffer in the presence of proteinase inhibitors and two cycles of nuclease treatment. Extensive PBS washes after each step and at the end of process were applied to wash out cell remnants and chemical residuals. The method was developed with care to cause minimal damage to the extracellular matrix (ECM) and produced biocompatible acellular porcine pulmonary roots that were devoid of cells and the $\alpha$-gal epitope, and minimal effects on the biomechanical and hydrodynamic function of the valves. The decellularization approach described in this study was suitable for pulmonary root conduits in the size 20$24 \mathrm{~mm}$. Modifications to the process may be required for conduits of smaller size from younger pigs.

There was no evidence of cells in the acellular tissue, as determined by histology and Hoescht, vWF, and vimentin staining, whereas the histoarchitecture of the ECM was not affected by the process. TEM analysis of the leaflet tissues showed no obvious sign of damage to the collagen fibers. The levels of fibronectin were reduced, particularly near the surface of the acellular tissues compared with fresh tissue indicating partial removal during the wash cycles. Collagen type IV was used as a marker for the basement membrane, which is believed to be important for endothelialization. ${ }^{33}$ The acellular pulmonary roots were devoid of collagen type IV staining, which was in contrast to studies reported by others for SDS-decellularized porcine pulmonary valve. ${ }^{34}$ Recent data within our group have suggested that the PAA treatment, and not the SDS treatment, abrogates collagen IV staining in decellularized porcine arteries (unpublished data). The PAA treatment could have removed collagen IV from the tissue or altered the collagen IV molecule such that the epitope recognized by the anti-collagen IV antibody was 


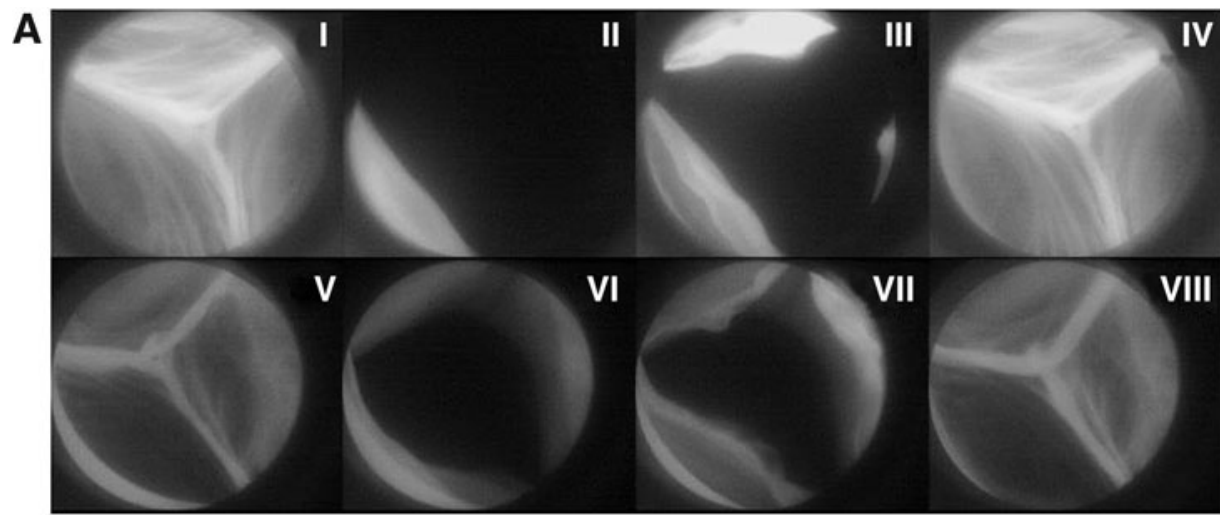

B

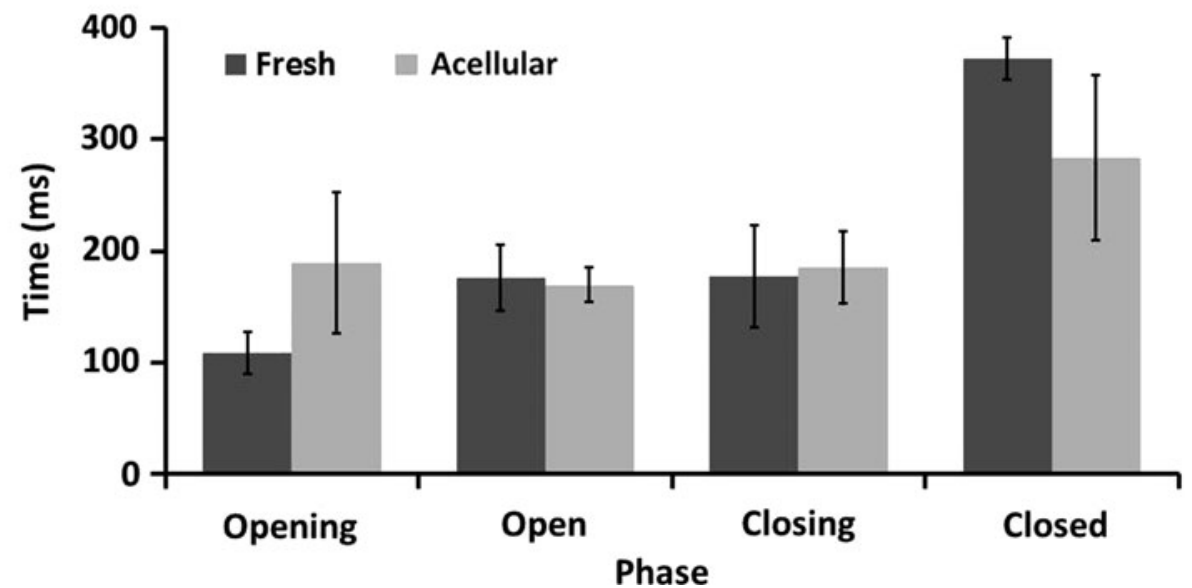

FIG. 8. Leaflet kinematics of fresh and acellular pulmonary roots. (A) Sequence of video images showing the deformation a representative fresh (I, II, III, IV) and acellular (V, VI, VII, VIII) left pulmonary leaflet (leaflet a) at start opening (I, V), fully open (II, VI), start closing (III, VII), and fully closed (IV, VIII) positions. (B) Phase times for the fresh $(n=6)$ and acellular $(n=6)$ pulmonary roots at test Condition 2. The error bars indicate the $95 \%$ CIs. No significant differences were found between the two groups. no longer available for binding. Whether this has an effect on the endothelialization of the roots will have to be revealed by further studies.

Determination of the DNA content of acellular biological scaffolds is considered to be important in determining the success of a decellularization protocol. ${ }^{35-37}$ Previous studies have shown that residual DNA is present in experimental and commercially available acellular biological scaffolds. ${ }^{38-40}$ Short lengths of DNA (less than $300 \mathrm{bp}$ ) are not considered to be of concern. ${ }^{38,41-43}$ Greater than $96 \%$ DNA removal was achieved for all regions with residual levels of less than $100 \mathrm{ng}$ per mg dry weight. A limitation of the methods used was that for the acellular tissue the readings in the Nanodrop spectrophotometer were at the lowest end of sensitivity of $2 \mathrm{ng} \cdot \mu \mathrm{L}^{-1}$. Thus, it was likely that the amount of residual DNA was in fact lower than it was actually found. It should be noted that, in the majority of studies of this nature, the
Picogreen assay is used to detect double-stranded DNA ${ }^{38}$ and not total DNA as reported here. PCR was used to determine target gene expression in the extracted DNA. Housekeeping genes were selected because they are universal in cell DNA. No PCR product was identified in any of the DNA samples extracted from the acellular tissues, providing further evidence of the removal of cellular DNA from the acellular tissue.

The $\alpha$-gal epitope is the major xenoantigen causing hyperacute rejection and $\alpha$-gal expressed by residual cells was reported to be the most likely reason for the failure of Synergraft (Cryolife) acellular xenograft heart valve. ${ }^{16}$ No evidence of residual $\alpha$-gal was identified in the acellular pulmonary valves by immunohistochemical staining or a previously adopted $\alpha$-gal absorption assay.

The hydroxyproline levels (representative of collagen) as a proportion of the mass of tissue were significantly higher
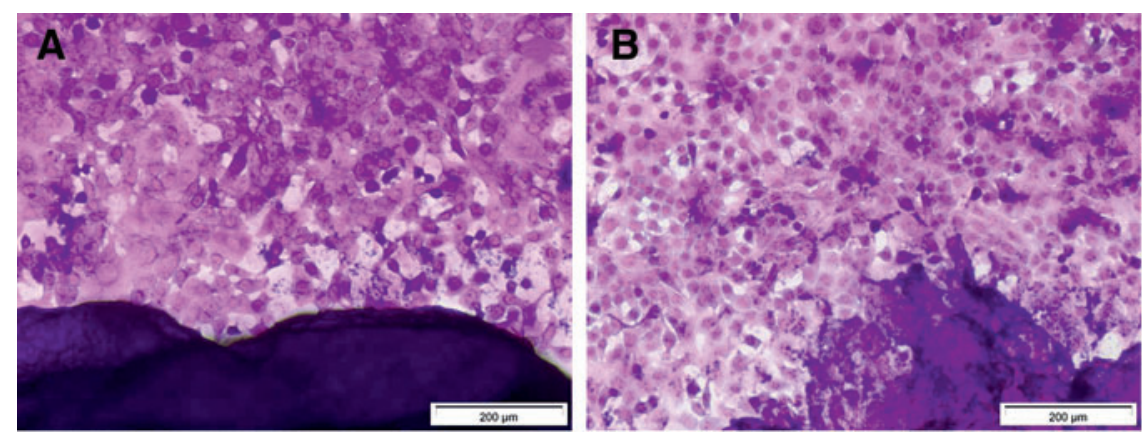

FIG. 9. Contact cytotoxicity assays of acellular porcine pulmonary leaflets and arteries following $48 \mathrm{~h}$ culture with murine 3 T3 fibroblasts. (A) Pulmonary leaflet adhered with collagen gel, $100 \times$; (B) Pulmonary artery adhered with steri strips, $100 \times$. Color images available online at www .liebertpub.com/tea 

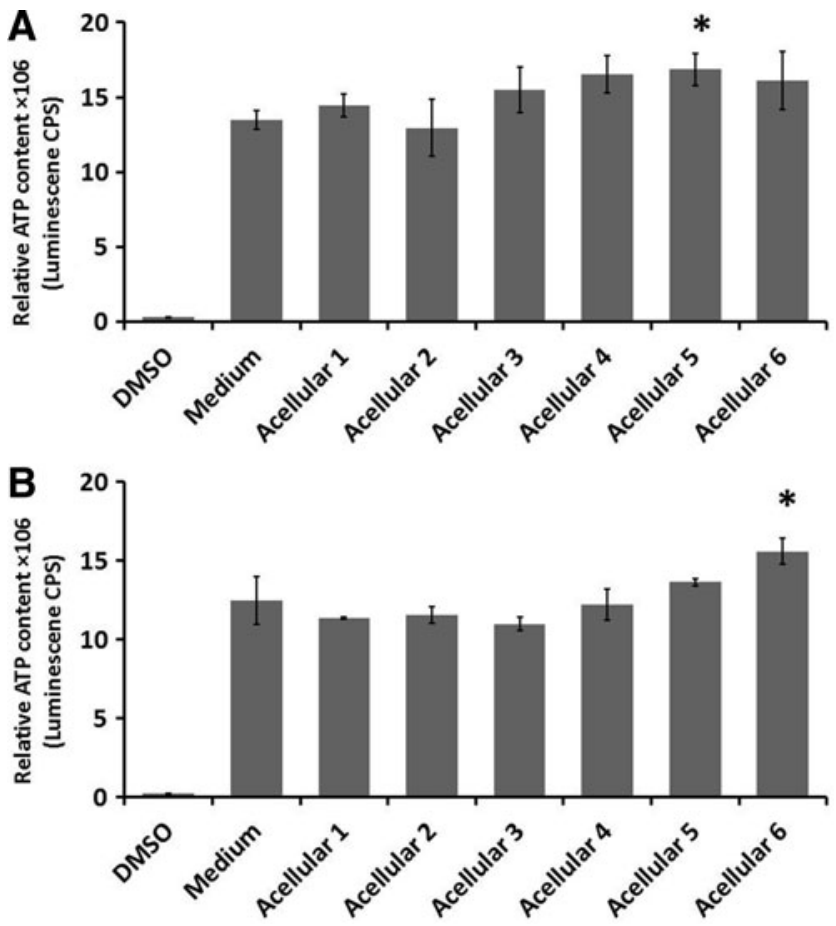

FIG. 10. Cell viability of murine $3 \mathrm{~T} 3$ fibroblasts (A) and BHK cells (B) following $72 \mathrm{~h}$ cultured in vitro with acellular porcine pulmonary artery extracts. Data are presented as the mean $(n=6) \pm 95 \%$ CI. Data were analyzed using one-way ANOVA followed by calculation of the MSD by the Tmethod $(p<0.05)$. “*'”Indicates a significant difference when compared with the medium only negative control group.

in the acellular pulmonary leaflet and artery than in the fresh tissue. The most likely reason was due to the loss of cell mass following decellularization. There was significant increase in the denatured collagen content of the arterial wall tissue, but not in the leaflet tissue following decellularization, which was most likely due to the trypsin treatment applied to the wall to aid the diffusion of the decellularization solutions. A significant reduction in the GAG level was observed in the pulmonary leaflet and pulmonary arteries following decellularization. Similar findings of GAG loss have been reported for different types of tissues decellularized using SDS. ${ }^{44,45}$ Since GAG is the major component in the spongiosa of the pulmonary leaflets it was important to examine the effect of GAG loss on the hydrodynamic function of the acellular valves.

There was no significant difference in the tensile properties of the acellular tissue compared with fresh except for a significant decrease in the elastin phase slope in both the circumferential and axial directions of the acellular arterial wall. Similar changes have been described by Korossis et $a l .{ }^{28}$ for porcine aortic conduits. This indicated that decellularization produced a more compliant tissue in the initial elastin phase (physiological range). The fact that no changes in the collagen phase slope, ultimate stress, or failure strain were demonstrated indicated that the small increase in denatured collagen in the arterial wall did not affect the strength of the acellular pulmonary root. The hydrodynamic performance and leaflet kinematics of the acellular pulmonary roots were similar to the fresh valves. The hydrodynamic performance of the fresh porcine pulmonary roots was compared to the pulmonary homograft (the current gold standard) ${ }^{46}$ and the fresh porcine pulmonary roots tested by others ${ }^{47}$ under similar conditions. The pressure drops generated by the fresh pulmonary roots in this study complied to previous studies. ${ }^{46,47}$ The hydrodynamic performance of the acellular roots was similar to the fresh roots. No significant difference was observed for either EOA or leaflet phase durations between the decellularized and fresh pulmonary roots, in any of the flow conditions used. These results demonstrated that the decellularization process and reduction in GAG levels in the acellular valves did not adversely affect the functional performance of the acellular pulmonary roots.

Currently available acellular xenogeneic pulmonary heart valve scaffolds have shown clinical outcomes ${ }^{17-20}$ that have indicated the need for the development of acellular valved conduits that are devoid of cells, DNA and residual $\alpha$-gal. To the authors' knowledge, this is the first study that has assessed the total DNA and the presence of $\alpha$-gal in all regions (leaflets, pulmonary wall, myocardium, and leaflet connection) of an acellular porcine pulmonary root conduit. The absence of functional housekeeping genes in the acellular conduit also provided further evidence of the removal of cellular DNA. Furthermore, the biomechanical and hydrodynamic properties of the conduit indicated that this level of cell and antigen removal was achieved without compromising the biomechanical attributes of conduit.

In conclusion, the acellular porcine pulmonary roots have excellent potential for development as valve substitutes for RVOT reconstruction e.g., during the Ross procedure. The regenerative potential of the acellular conduits will be assessed in future studies, in a suitable large animal model.

\section{Acknowledgments}

Funding support was from the British Engineering and Physical Science Research Council (EPSRC). EPSRC studentship to Ji Luo and through the Leeds Centre of Excellence in Medical Engineering funded by the Wellcome Trust and EPSRC, WT088908/z/09/z.

\section{Disclosure Statement}

Eileen Ingham, John Fisher, Stacy-Paul Wilshaw, and Sotirios Korossis are shareholders in Tissue Regenix Group PLC. Eileen Ingham and John Fisher act as consultants for the company.

\section{References}

1. Sapirstein, J.S., and Smith, P.K. The "ideal" replacement heart valve. Am Heart J 141, 856, 2001.

2. Booth, C., Korossis, S.A., Wilcox, H.E., Watterson, K.G., Kearney, J.N., Fisher, J., and Ingham, E. Tissue engineering of Cardiac valve prostheses I: development and histological characterization of an acellular porcine scaffold. J Heart Valve Dis 11, 457, 2002.

3. Vesely, I. Heart valve tissue engineering, Circ Res 97, 743, 2005. 
4. Ross, D.N. Replacement of aortic and mitral valves with a pulmonary autograft. Lancet 2, 956, 1967.

5. Da Costa, F.D., Dohmen, P.M., Duarte, D., von Glenn, C., Lopes, S.V., Filho, H.H., et al. Immunological and echocardiographic evaluation of decellularized versus cryopreserved allografts during the Ross operation. Eur J Cardiothorac Sur 27, 572, 2005.

6. Da Costa, F., Dohmen, P., Vieira, E., Lopes, S.V., Colatusso, C., Pereira, E.W.L., Matsuda, C.N., and Cauduro, S. Ross operation with decelularized pulmonary allografts: medium-term results. Rev Bras Cir Cardiovas 22, 454, 2007.

7. Clarke, D.R., Campbell, D.N., Hayward, A.R., and Bishop, D.A. Degeneration of aortic valve allografts in young recipients. J Thoracic Cardiovasc Surg 105, 934, 1993.

8. Brown, J.W., Ruzmetov, M., Vijay, P., and Turrentine, M.W. Clinical outcomes and indicators of normalization of left ventricular dimensions after Ross procedure in children. Semin Thorac Cardiovasc Surg 13, 28, 2001.

9. Brockbank, K.G., Lightfoort, F.G., Song, Y.C., and Taylor, M.J. Interstitial ice formation in cryopreserved homografts: a possible cause of tissue deterioration and calcification in vivo. J Heart Valve Dis 9, 200, 2000.

10. Costa, F.D.A, Santos, L.R., Collatusso, C., Matsuda, C.N., Lopes, S.A.V., Caudoro, S., Roderjan, J, and Ingham, E. Thirteen years' experience with the Ross operation. J Heart valve Dis 18, 84, 2009.

11. Navarro, F.B., Costa, F.D.A., Mulinari, L.A., Pimentel, G.K., Roderjan, J, G., Vieira, E.D., Noronha, L., and Miyague, N.I. Evaluation of the biological behaviour of decellularized pulmonary homografts: an experimental sheep model. Rev Bras Cir Cardiovasc 25, 377, 2010.

12. Bader, A., Schilling, T., Teebken, O.E., Brandes, G., Herden, T., Steinhoff, G., and Haverich, A. Tissue engineering of heart valves-human endothelial cell seeding of detergent acellularized porcine valves. Eur J Cardiothorac Surg 14, 279, 1998.

13. Schenke-Layland, K., Vasilevski, O., Konig, F., Riemann, I., Halbhuber, K.J., Wahlers, T., and Stock, U.A. Impact of decellularization of xenogeneic tissue on extracellular matrix intergrity for tissue engineering of heart valves. Struct Biol 143, 201, 2003.

14. Wilson, G.J., Courtman, D.W., Klement, P., Lee, J.M., and Yeger, H. Acellular matrix: a biomatirials approach for coronary-artery bypass and heart valve replacement. Ann Thorac Surg 60, 353, 1995.

15. Brown, J.W., Ruzmetov, M., Eltayeb, O., Rodefeld, M.D., and Turrentine, M.W. Performance of SynerGraftdecellularized pulmonary homograft in patients undergoing a Ross procedure. Ann Thorac Surg 91, 416, 2011.

16. Simon, P., Kasimir, M.T., Seebacher, G., Wigel, G., Ullrich, R., Salzer-Muhar, U., Rieder, E., and Wolner, E. Early failure of the tissue engineered porcine heart valve SYNERGRAFT in pediatric patients. Eur J Cardiothorad Surg 23, 1002, 2003.

17. Ruffer, A., Purbojo, A., Cicha, I., Glockler, S.P., Dittrich, S., and Cesnjevar, R.A. Early failure of xenogenous decellularised pulmonary valve conduits-a word of caution! Eur J Cardio Thorac 38, 78, 2010.

18. Konertz, W., Angeli, E., Tarusinov, G., Christ, T., Kroll, J., Dohmen, P.M., Krogmann, O., Franzbach, B., Napoleone, C., and Gargiulo, G. Right ventricular outflow tract reconstruction with decellularized porcine xenografts in pa- tients with congenital heart disease. J Heart Valve Dis 20, 341, 2011.

19. Mahler, G.J., and Butcher, J.T. Inflammatory regulation of valvular remodeling: the Good, the bad, and the ugly. Int J Inflam 2011, 721419, 2011.

20. Cicha, I., Ruffer, A., Cesnjevar, R., Glöckler M, Agaimy, A., Daniel, W.G., Garlichs, C.D., and Dittrich, S. Early obstruction of decellularized xenogeneic valves in pediatric patients: involvement of inflammatory and fibroproliferative processes. Cardiovasc Pathol 20, 222, 2011.

21. Wilcox, H.E., Korossis, S.A., Booth, C., Watterson, K.G., Kearney, J.N., Fisher. J., and Ingham, E. Biocompatibility and recellularization potential of an acelluar porcine heart valve matrix. J Heart Valve Dis 14, 228, 2005.

22. Mirsadraee, S., Wilcox, H.E., Korossis, S.A., Kearney, J.N., Watterson, K.G., Fisher, J., and Ingham, E. Development and characterization of an acellular human pericardial matrix for tissue engineering. Tissue Eng 12, 763, 2006.

23. Edwards, C.A., and O'Brien, W.D., Jr. Modified assay for determination of hydroxyproline in a tissue hydrolyzate. Clin Chim Acta 104, 161, 1980.

24. Bank, R.A., Krikken, M., Beekman, B., Stoop, R., Maroudas, A., Lafeber, F.P., and teKoppele, J.M. A simplified measurement of degraded collagen in tissues: application in healthy, fibrillated and osteoarthritc cartilage. Matrix Biol 16, 233, 1997.

25. Stapleton, T.W., Ingram, J., Katta, J., Knight, R., Korossis, S., Fisher, J., and Ingham, E. Development and characterization of an acellular porcine medial meniscus for use in tissue engineering. Tissue Eng 14, 505, 2008

26. Korossis, S.A., Booth, C., Wilcox, H.E., Watterson, K.G., Kearney, J.N., Fisher, J., and Ingham, E. Tissue engineering of cardiac valve prostheses II: biomechanical characterization of decellularized porcine aortic heart valves. J Heart Valve Dis 11, 463, 2002.

27. Revanna, P., Fisher, J., and Watterson, K.G. The influence of free hand suturing technique and zero pressure fixation on the hydrodynamic function of aortic root and aortic valve leaflets. Eur J Cardiaothorac Surg 11, 280, 1997.

28. Korossis, S.A., Wilcox, H.E., Watterson, K.G., Kearney, J.N., Ingham, E., and Fisher, J. In-vitro assessment of the functional performance of the decellularized intact porcine aortic root. J Heart Valve Dis 14, 408, 2005.

29. Gabbay, S., McQueen, D.M., Yellin, E.L., Becker, R.M., and Frater, R.W. In vitro hydrodynamic comparison of mitral valve prostheses at high flow rates. J Thorac Cardiovasc Surg 76, 771, 1978.

30. Sokal, R.R., and Rohlf, F.J. Biometry. New York: W.H. Freeman \& Company, 1981.

31. Thubrika, M., Bosher, P.L., and Nolan, S.P. The mechanism of opening of the aortic valve. J Thorac Cardiov Sur 77, 863, 1979.

32. Jennings, L.M., Butterfield, M., Booth, C., Watterson, K.G., and Fisher, J. The pulmonary bioprosthetic heart valve: its unsuitability for use as an aortic valve replacement. J Heart valve Dis 11, 668, 2002

33. Brown, B., Lindberg, K., Reing, J., Stolz, D.B., and Badylak, S.F. The basement membrane component of biologic scaffolds derived from extracellular matrix. Tissue Eng 12, 519, 2006.

34. Tudorache, I., Cebotari, S., Sturz, G., Kirsch, L., Hurschler, C., Hilfiker, A., Haverich, A., and Lichtenberg, A. Tissue 
engineering of heart valves: biomechanical and morphological properties of decellularized heart valves. J Heart Valve Dis 16, 567, 2007.

35. Zheng, M.H., Chen, J., Kirilak, Y., Willers, C., Xu, J., and Wood, D. Porcine small intestine submucosa (SIS) is not an acellular collagenous matrix and contains porcine DNA: possible implications in human implantation. J Biomed Master Res B Appl Biomater 73, 61, 2005.

36. Lotze, M.T., Deisseroth, A., and Rubartelli, A. Damage associated molecular pattern molecules. Clin Immunol 124, 1, 2007.

37. Nagata, S., and Hanayama, R. Autoimmunity and the clearance of dead cells. Cell 140, 619, 2010.

38. Gilbert, T.W., Freund, J.M., and Badylak, S.F. Quantification of DNA in biologic scaffold materials. J Surg Res 152, 135, 2009.

39. Boer, U., Lohrenz, A., Klingenberg, M., Pich A., Haverich, A., and Wilhelmi, M. The effect of detergent-based decellularization procedures on cellular proteins and immunogenicity in equine carotid artery grafts. Biomaterials 32, 9730, 2011.

40. Wilshaw, S., Rooney, P., Berry, H., Kearney, J., HomerVanniasinkam, S., Fisher, J., and Ingham, E. Development and characterisation of acellular allogeneic arterial matrices. Tissue Eng Part A 18, 471, 2011.

41. Bennett, R.M., Gabor, G.T., and Merritt, M.M. DNA binding to human leukocytes. Evidence for a receptormediated association, internalization, and degradation of DNA. J Clin Invest 76, 2182, 1985.

42. McCoy, S.L., Kurtz, S.E., Hausman, F.A., Trune, D.R., Bennett, R.M., and Hefeneider, S.H. Activation of RAW264.7 macrophages by bacterial DNA and lipopolysaccharide increases cell surface DNA binding and internalization. J Biol Chem 279, 17217, 2004.
43. Gilbert, T.W., Stewart-Akers, A.M., Simmons-Byrd, A., and Badylak, S.F. Degradation and remodeling of small intestinal submucosa in canine Achilles tendon repair. J Bone Joint Surg Am 89, 621, 2007.

44. Stapleton, T.W., Ingram, J., Katta, J., Knight, R., Korossis, S., Fisher, J. and Ingham, E. Development and characterization of acellular porcine medical meniscus for use in tissue engineering. Tissue Eng Part A 14, 505, 2008.

45. Cheng, H., Tsui, Y., Cheung, K., Dan, D., and Chan, B. Decellularization of chondrocyte-encapsulated collagen microspheres: a three-dimensional model to study the effects of acellular matrix on stem cell fate. Tissue Eng Part C 15, 697, 2009.

46. Weerasena, N., Lockie, K.J., Butterfield, M., Fisher, J., Kearney, J.N., and Davies, G.A. The hydrodynamic function and leaflet dynamics of aortic and pulmonary roots and valves: an in vitro study. Eur J Cardio Thorac 6, 350, 1992.

47. Nagy, Z.L., Fisher, J., Walker, P.G., and Watterson, K.G. The in vitro hydrodynamic characteristics of the porcine pulmonary valve and root with regard to the Ross procedure. J Thorac Cardiovasc Surg 120, 284, 2000.

Address correspondence to: Ji Luo, PhD

Institute of Medical and Biological Engineering The University of Leeds Leeds LS2 9JT United Kingdom

E-mail: j.1uo@leeds.ac.uk

Received: September 16, 2013 Accepted: April 25, 2014

Online Publication Date: June 9, 2014

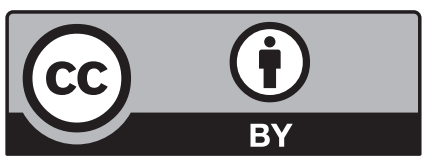

This work is licensed under a Creative Commons Attribution 3.0 United States License. You are free to copy, distribute, transmit and adapt this work, but you must attribute this work as "Tissue Engineering, Part A. Copyright 2014 Mary Ann Liebert, Inc. http://liebertpub.com/tea, used under a Creative Commons Attribution License: http://creativecommons.org/licenses/by/3.0/us/" 